\title{
Vær velkommen Herrens Aar og velkommen herhid!
}

\author{
Af Jette Holm
}

Indledningsvis skitseres Grundtvigs syn på den gamle tekstrække som baggrund for salmerne Voer velkommen Herrens Aar og velkommen herhid!

Den 2. december 1849 bringer Dansk Kirketidende en gammel tekst: Wer welkommen, Herrens Aar, och wellkommen herre! Teksten er fundet af Grundtvigs søn Svend Grundtvig. ${ }^{1}$ Det oplyses samtidigt, at der også findes en gammel tekst til det borgerlige nytår. Disse to tekster bliver anledning til N. F. S. Grundtvigs salmer: "Vær velkommen Herrens Aar, og velkommen herhid". Grundtvig prædiker over sine nydigtede salmer på henholdsvis 1 . søndag i advent 1849 og nytårsdag 1850, hvor de synges af menigheden i Vartov. Hans prædikentekster bringes her for første gang på tryk.

\section{Kirkeårets tekster}

Grundtvigs syn på kirkeårets tekstrække gennemgår en udvikling, fra ansatser til en historisk ordning af evangelierne til en fuldtonende pris af den gamle tekstrække som Helligåndens skabning.

Grundtvig siger i sin prædiken 1. søndag i advent 1836, at han dunkelt husker, hvordan salmen "Fryd dig, du Christi Brud! med det velsignede Omkvæd: Hosianna, Hæder og Ære skal denne vor Konning være!”2 frydede ham som barn på 1. søndag i advent. Selv om teksten hører hjemme før påske. Det betyder ikke, at der til alle tider skal prædikes over denne tekst ved kirkeårets begyndelse, for i kirken er der frihed, og der savnes mange tekster fra Det Nye Testamente. Men når man hvert år ville læse "Hoved-Stykkerne af Herrens Levnet, fra Hans Bebudelse til Hans Himmelfart", ${ }^{3}$ så vil menigheden gøre en undtagelse med denne læsning i begyndelsen af kirkeåret, ligesom fædrene, mener Grundtvig. Men hans ønske er, at kirkeårets tekster ordnes efter det historiske forløb i Jesu liv. Sådan at for eksempel Jesu dåb og fristelse kommer før brylluppet i Kana, hvor Jesus gjorde sit første tegn. ${ }^{4}$

Omkring 1832 lavede Grundtvig sin egen liste med ændrede tekster til kirkeåret, historisk ordnet. Men selv om han havde lov til et friere tekst-

\footnotetext{
${ }^{1}$ Svend Grundtvig (1824-83) var opkaldt efter nordmanden Svend Hersleb (17841836), faderens ven på Valkendorfs Kollegium. Han blev dog døbt Svenn, en form, han brugte på tryk 1842-46, men fra og med 1847 rettede til Svend, og uanset kilde er det normaliseret dertil i det følgende.

${ }^{2} G P \times, 78$.

${ }^{3} G P$ sst.

${ }^{4}$ Se GPV III, 60, og kommentarbd. IV, 340 f.
} 
valg som præst i Frederikskirken, afstod han fra det og holdt sig til den gamle tekstrække. ${ }^{5}$

I Frisprog mod H. H. Hr. Biskop Mynsters Forslag til en ny Forordnet Alterbog, 1839, ${ }^{6}$ har Grundtvig et afsnit om "Texter og Helligdage". Han er ikke imod inddragelse af flere tekster fra Bibelen, men imod den tvang, som Mynsters alterbog foreskriver, og kritiserer den foreslåede vekslen af evangelier og epistler på 2 tekstrækker og 3. tekstrækkes atomare og tilfældige sammenstykning. Han mangler et organisk, samlende hele, for eksempel et historisk, dogmatisk eller moralsk. Grundtvig nævner, at han selv blev overbevist om den gamle tekstrækkes værdi, da han i Frederikskirken havde haft mulighed for at vælge andre tekster.

Vilhelm Birkedals lille bog om Kirkeaaret, et Billede paa den christelige Livsudvikling fra 1843, der er affødt af Frisproget, gør stort indtryk på Grundtvig. Han skriver i et brev til Birkedal, at den eneste "organisme", han hidtil har set i årets evangelier, er den historiske, men ser nu en anden helhed, kirkeåret som et billede på den kristelige livsudvikling, som Birkedal forsøger at påvise i sin bog. ${ }^{7}$

25. søndag efter trinitatis, 1849 (25. nov.), ${ }^{8}$ prædiker Grundtvig i Vartov. Her møder vi hans syn på årets evangelietekster som "et Heelt", en levende skabning til menighedens oplysning og opbyggelse, trøst og formaning, skabt af Helligånden. Selv om der findes mange andre tekster i Bibelen, har årets evangelietekster næsten alle vandret med fædrene i snart tusinde år, så derfor kan ingen af dem undværes.

Grundtvig nævner også i denne prædiken, at han selv engang for en snes år siden havde ret til selv at vælge sine tekster. Men det var, som om han indvendig hørte en røst som profetens, der sagde: Fordærv ikke druen, der er en velsignelse i den! (Es 65,8). Og Grundtvig opdagede, at der var

et Liv i Søndags-Evangelierne og en levende Forbindelse imellem dem og hele Menigheden fra Slægt til Slægt, som vi umuelig kunde skabe til nogen anden Deel af den hellige Skrift, og som den Helligaand naturligviis ikke vilde skabe, dersom vi selvkloge paa vor egen Haand vilde forrykke og forandre hans Skabning, som han giennem mange Aarhundreder havde opholdt og velsignet. (Fasc. 40).

Søndagens evangelier var og er gennem mange århundreder

\footnotetext{
${ }^{5}$ Grundtvigs liste er udgivet af C. J. Brandt i Dansk Kirketidende 1874, (6), 81-86.

${ }^{6}$ US VIII, 257-270.

${ }^{7} B G$ II, 373-374 jf. 375-376.

${ }^{8}$ Prædikenen findes på www.grundtvig-byen.dk og i N. F. S. Grundtvigs Vartovs-Prcedikener 1839-1860. I Udvalg ved Holger Begtrup, (1924), 240-244; men citeres her efter manuskriptet i Fasc. 40.
} 
endnu ligesom Sjælen i alle vore christelige Betragtninger, ligesom Straalerne hvori det store Lys kom til de Utallige, som sad i Mørke og Dødens Skygge, og ligesom Livs-Aarerne hvorigiennem hele den evangeliske Fred og Trøst og Glæde giennemstrømmede Menigheden! (Fasc. 40).

Netop dette falder Grundtvig på sinde den sidste søndag i kirkeåret:

at alle vore Søndags-Evangelier skal betragtes som et levende Heelt, som et aandeligt Legeme skabt af Aanden til Christi Evangeliums levende Forkyndelse eens allevegne og hos alle Menigheder, (Fasc. 40).

Prædikenen på sidste søndag i kirkeåret 1849 foregriber salmerne Voer velkommen Herrens Aar og de tilhørende prædikener og er måske inspireret af Svend Grundtvigs fund af to gamle tekster.

\section{Vaer velkommen Herrens Aar og velkommen herhid!}

Anders Malling oplyser om salmerne til advent og nytår Voer velkommen, Herrens Aar, at Svend Grundtvig offentliggjorde en gammel, dansk adventssalme: Wer welkommen, Herrens Aar, och wellkommen herre! i Dansk Kirketidende, 2. dec. 1849. Svend Grundtvig havde fundet manuskriptet til den på Det Kongelige Bibliotek. Samtidigt oplyste Svend Grundtvig, at der fandtes en verdslig nytårsvise med samme omkvæd og versemål. ${ }^{9}$

Svend Grundtvig må have vist de gamle tekster til sin far, der laver en ny salme til 1. søndag i advent 1849,2. december, på et trykt salmeblad til Vartov menighed:

Vær velkommen Herrens Aar og velkommen herhid!

Julenat, da vor Herre blev fød,

Da tændte sig Lyset i Mørkets Skiød!

Velkommen Nytaar og velkommen her!

Vær velkommen Herrens Aar og velkommen herhid!

Paaskemorgen, da Herren opstod,

Da Livstræet fæsted i Graven Rod!

Velkommen Nytaar og velkommen her!

Vær velkommen Herrens Aar og velkommen herhid!

Pindsedag, da Guds Aand kom herned

Da straaled hans Kraft i vor Skrøbelighed!

Velkommen Nytaar og velkommen her!

Vær velkommen Herrens Aar og velkommen herhid!

Herrens Aar med vor Guds Velbehag

\footnotetext{
${ }^{9}$ Der henvises til ordlyden af de to gamle tekster i Mallings gennemgang. Anders Malling (1966), Dansk Salmehistorie, V, 223-227.
} 
Nu bringer os Glæde hver Herrens Dag!

Velkommen Nytaar og velkommen her! ${ }^{10}$

I julen 1849 får menigheden et mere omfattende salmeblad, der rummer Grundtvigs borgerlige nytårssalme: Voer velkommen Herrens Aar. ${ }^{11}$

Anders Malling og andre har analyseret indholdet $\mathrm{i}$ de to salmer; ${ }^{12}$ men hvad salmeforskningen hidtil ikke har været opmærksom på, er, at Grundtvig prædiker over sine to nye salmer på henholdsvis 1 . søndag $i$ advent 1849 og nytårsdag $1850^{13}$. I de to prædikener udlægger Grundtvig selv sine salmer.

\section{1. søndag i advent, 1849}

Grundtvig starter det nye kirkeår, 1. søndag i advent 1849, hvor han sluttede sidste søndag i kirkeåret, med en omtale af kirkeårets evangelier. Når det er sandt, at søndagenes evangelier udgør en sand apostel-prædiken i Åndens kraft, og at dåb og nadver opfylder, hvad apostel-prædikenen spår og lover, så er der vel grund til at hilse hvert kirkeår velkommen med et Hosianna af hjertensgrund, som dagens evangelium opmuntrer til.

Og see m. V. vi har idag faaet en ny Opmuntring til at hilse Aaret, som kommer i Herrens Navn med et frydefuldt Hosianna, da vi just til idag har faaet Kundskab om den deilige Hilsen til det kirkelige Nytaar, som fødtes i fordums Tid paa Fædrenes Læber, og var længe forstummet og forglemt, men er just derfor skikket til at faae dobbelt liflig Klang paa vore Tunger.

Ja, vær velkommen Herrens Aar og velkommen herhid! velkommen Nytaar og velkommen her! det kan vi alle høre, er ret et ægte Dansk Hosianna, hvori Munden taler af Hjertets Overflødighed (Fasc. 41).

1. søndag i advent 1849 byder Grundtvig kirkeåret velkommen, ligesom folkeskaren i evangeliet byder Jesus velkommen med råbet: Hosianna i det høje. På dansk altså ifølge Grundtvig: Vær velkommen Herrens år og velkommen herhid! På 1. søndag i advent 1836 forsøger Grundtvig sig med et "Hurra i vilden Sky" som den verdslige version af Hosianna! ${ }^{14}$ Men nu har han fundet det udtryk, som tiltaler ham, det ægte danske: "Vær velkommen!", som fædrene har sunget, og som nu er genfundet.

\footnotetext{
${ }^{10}$ GSV IV, 247.

${ }^{11}$ Grundtvigs manuskripter til de to nye salmer findes ikke, men hele den borgerlige nytårssalme gengives i Grundtvigs prædikenmanuskript til nytårsdag 1850 . (Se nedenfor).

12 Jf. Anders Malling, (1966), Dansk Salmehistorie, V, 223-227.

${ }^{13}$ Da prædikenerne aldrig har været trykt, bringes den fuldstændige tekst nedenfor fra Fasc. 41.

${ }^{14}$ GP X, 79.
} 
Herrens år bringer velsignelse. Det gør ethvert kirkeår, men det er vigtigt, hvordan det modtages. Herrens år er nådens, fredens og glædens år. Andre ord for "retfærdighed og fred og glæde i Helligånden" (Rom 14,17). Sådan er det for de kristne.

Salmen havde fra begyndelsen den form, som vi kender i dag. Dog med den undtagelse, at det i 3. strofe om pinsen hedder: "Pindsedag, da Guds Aand kom herned, / Da straaled hans Kraft i vor Skrøbelighed!".

I prædikenen understreger Grundtvig, at vi er

endnu langtfra at kunne værdelig beskrive al den Velsignelse, som Herrens Aar har at bringe, men af hvad Art den er, det veed vi dog fra det første Øieblik, vi troe paa Jesus Christus Gud og Mand, vor Frelser og Gienløser fra Synd og Død og hele Satans Rige, thi ligefra den Stund veed vi det, at Herrens Aar er Naadens og Fredens og Gloedens Aar, mageløs rige paa Velsignelse fra den første Stund, de oprinder over os, saa vi deraf kan slutte hvad de maa være, naar de krones med Velsignelse som Aaret om Høsten, saa Naaden virker med hele sin Guddoms-Kraft og Varme, og Freden blomstrer i hele sin himmelske Frugtbarhed og Glæden straaler i hele sin uforkrænkelige Glands og Klarhed! (Fasc. 41).

Adventssalmen Veer velkommen Herrens Aar nævner de 3 store højtider, jul, påske og pinse og opsummerer i 4. strofe hele kirkeåret: "Herrens Aar med vor Guds Velbehag / Nu bringer os Glæde hver Herrens Dag!" Det Herrens år og de Herrens dage med apostelprædikenen og sakramenterne, hvor søndagenes gamle tekster nu har fået ny betydning som Helligåndens skabning.

Det er værd at lægge mærke til, at denne prædiken beskriver Herrens år som nådens, fredens og gladens år. De betegnelser, der ligger nær den verdslige nytårssalme få uger senere.

\section{Nytårsdag 1850}

Prædikenen på nytårsdag 1850, der bringer hele ordlyden af Grundtvigs (borgerlige) nytårssalme, som også er blevet sunget af menigheden, gennemgår da også forskellen på en nytårssalme henvendt til den kristne menighed og en salme til det borgerlige nytår. Grundtvig befandt sig midt i Treårskrigen, hvor begge hans sønner var med som frivillige, og salmen og prædikenen på nytårsdag 1850 er skrevet med håb for Danmark og Norden i det nye år.

Grundtvig præciserer i denne nytårsprædiken, hvad man med rette kan bede Gud om for det borgerlige samfund. Hvor bønnen må rettes til Gud som fader og skaber. Hvor Gud påkaldes som Sandheds, Nådens og Fredens Gud og tiltales som Fader-Gud; for menneskelig sanddruhed, ærlighed, mildhed, godgørenhed og fredsommelighed er Gud velbehagelige $\mathrm{i}$ al deres jordiske svaghed og fattigdom. Og Danmark og Norden er fra Arildstid netop alt dette. 
Grundtvig gav udtryk for sit ønske om, at den kristne menighed hvert år således ville byde Herrens år velkommen med salmen: Voer velkommen Herrens Aar og velkommen herhid!

Det ønske er gået i opfyldelse, nu hvor salmerne hører uløseligt til, både i kirken og det borgerlige nytår, og Grundtvigs egen baggrund og tolkningen i prædikenerne kan være med til at uddybe de to salmer.

\section{[Grundtvig-prædiken i Vartov. Fasc. 41]}

\section{Nyt Kirkeaar 1849-50. 1ste Advents-Søndag}

Hellige Gud Fader! Himmelens og Jordens Skaber! hellige Du os i Din Sandhed! Dit Ord er Sandhed! Dit Ord til os er Aand og Liv! lad det veere os noer, $i$ vor Mund og $i$ vort Hjerte, det Troens Ord, som maa høres! ja, Himmelske Fader! lad Vorherres Jesu Christi Evangelium, som Dit Ord i Din Aands Kraft og med Din faderlige Velsignelse, stedse klarere bevise at Dine Aar faaer aldrig Ende, Du er god og Din Miskundhed varer evindelig! Bønhør os i Vorherres Jesu Christi Navn: vor Fader, Du, som er i Himlene!

Christne Venner! med denne Herrens Dag begynder vi et kirkeligt Nytaar, og er det sandt, at vore Søndags-Evangelier udgiør ogsaa paa vort Modersmaal, en sand evangelisk Apostel-Prcediken i Aandens Kraft, hvorved vi kaldes, forsamles, oplyses og opbygges, og at Daaben og Nadveren, som Vorherres Jesu Christi egne Indstiftelser og Guddoms-Gierninger opfylder hos den troende Menighed alt hvad den evangeliske Apostel-Prædiken spaaer og lover, er det kun sandt, og det er visselig sandt, da maae vi vel hilse hvert Aar, som kommer til os i Herrens Navn med et Hosianna af Hjertensgrund som Dagens Evangelium opmuntrer os til ved det apostoliske Vidnesbyrd om Herrens Indtog i Jerusalem under Folkets Jubel, som bredte deres Klæder paa hans Vei, bar Palmer for ham som den store Seierherre og raabde Hosianna for Davids Søn! Hosianna i det Høie!

Og see m. V. vi har idag faaet en ny Opmuntring til at hilse Aaret, som kommer i Herrens Navn med et frydefuldt Hosianna, da vi just til idag har faaet Kundskab om den deilige Hilsen til det kirkelige Nytaar, som fødtes i fordums Tid paa Fædrenes Læber, og var længe forstummet og forglemt, men er just derfor skikket til at faae dobbelt liflig Klang paa vore Tunger.

Ja, vær velkommen Herrens Aar og velkommen herhid! velkommen Nytaar og velkommen her! det kan vi alle høre, er ret et ægte Dansk Hosianna, hvori Munden taler af Hjertets Overflødighed, og har vi nu kun Hjertelag til at byde Herrens Aar saaledes velkommen, da skal vi alle føle, det er et godt Tegn og lykkeligt Forvarsel, som spaaer os, at 
ligesom Velkomsten er, saa skal Velsignelsen blive dette Aar og herefter, ja, blive endda meget bedre, blive saameget overflødigere, som Vorherre Jesus Christus er baade bedre og rigere end nogen af os.

Vorherre og Hans Aar er nemlig vel i dem selv altid lige gode og rige paa Velsignelse, men de er dog langtfra altid at nydes lige godt eller at komme alle eens tilgode, fordi os skeer kun, som vi troer, vi faaer kun som vi bede, og Herrens Aar saavelsom han selv drager kun ind til os med saamegen Velsignelse, som vi er skikkede til at modtage, saa vil vi have Velsignelsens Fylde, da maae vi giøre Dørrene høie og Portene vide, som skrevet staaer: op med eder, I Porte og evige Dørre, at Ærens Konge kan komme ind!

Gid det derfor kun ved hvert Kirkeaars Begyndelse maa bestandig lyde høiere og tone lifligere af Hjertens Grund: vær velkommen Herrens Aar og velkommen herhid! velkommen Nytaar! og velkommen her! saavist som da vi og vore Børn i Herren skal altid bedre af en lyksalig Erfaring lære at kiende Christi Evangeliums Velsignelses Fylde, saa skiøndt Evangelierne er de gamle, Herren og hans Ord, Troen og Haabet og Kiærligheden er altid de samme, saa skal dog hvert Kirkeaar være et Nytaar, et lyksaligt Nytaar for den hele Menighed, fordi Troen befæstes, Haabet styrkes og Kiærligheden voxer, saa Herrens virkelige Nærværelse og den evige Velsignelse, som følger ham, føles altid med ny Forundring og Glæde under Hjertets og Sjælens Forvandling fra Klarhed til Klarhed i hans Ansigts Lys!

Ja m. V. ligesom der staaer skrevet om Herrens Aar, at de er af Evigheden, saaledes er ogsaa Velsignelsen, de har at bringe, en evig Velsignelse og den er rig, som Kilden, hvoraf den udstrømmer, men indstrømmer kun, som den indbydes og indlades, som det lyder i Davids-Psalmen: Herre! Du besøger Jorden og naar Du har gjort den begiærlig, giør Du den meget rig, du kroner Aaret med din Godhed og dine Fodspor dryppe med Fedme. Derfor er vi endnu langtfra at kunne værdelig beskrive al den Velsignelse, som Herrens Aar har at bringe, men af hvad Art den er, det veed vi dog fra det første Øieblik, vi troe paa Jesus Christus Gud og Mand, vor Frelser og Gienløser fra Synd og Død og hele Satans Rige, thi ligefra den Stund veed vi det, at Herrens Aar er Naadens og Fredens og Gloedens Aar, mageløs rige paa Velsignelse fra den første Stund, de oprinder over os, saa vi deraf kan slutte hvad de maa være, naar de krones med Velsignelse som Aaret om Høsten, saa Naaden virker med hele sin Guddoms-Kraft og Varme, og Freden blomstrer i hele sin himmelske Frugtbarhed og Glæden straaler i hele sin uforkrænkelige Glands og Klarhed!

Ja m. V. ligesom al Verden veed, at Christi Evangelium er et mageløst Naadens Ord, saaledes lære alle Christne, Alle de, som troer Evangeliet, at kiende Herrens Aar, som Naadens Tid, Mildhedens og den uforskyldte Godheds Tid, der ikke vil nogen Synders Død, men at han skal omvende sig og leve, og det kan vi alle føle, at i samme Grad som 
denne Guds Naade med Syndernes Forladelse og det evige Livs Haab troes, annammes og virker med Guddoms-Kraft, i samme Grad og Maal nyder vi Velsignelsen af Herrens Aar, som den velbehagelige Tid med Salighedens Dag, thi naar det indskrives i vort Hjerte med den levende Guds Aande, at Syndens Sold er Død, men Guds Naadegave er et evigt Liv i Jesus Christus Vorherre, da føle vi, at med det samme indskrives vore Navne i Livets Bog til ei at udslettes evindelig!

Fremdeles, saa ligesom Christi Evangelium vitterlig er et mageløst Fredens Ord, hvormed Guds Fred udraabes og tilbydes ja, tilraades os saa indtrængende, at vi vel i Hjertets, i Kiærlighedens Sprog maae sige, den nødes os paa, saaledes troer ingen paa Vorherre Jesus Christus, som den store Mægler mellem Gud og Menneske, der selv blev en Forligelse og Sone-Offer for vore, for al Verdens Synder, Ingen troer saaledes paa Christus uden at Herrens Aar bringer dem den Guds Fred, der overgaaer al vor Forstand, den Hjertets og Tankernes Rolighed ved en opvakt Samvittigheds Røst, der er Lovens Torden, som man skulde tænke umuelig kunde indgaae i en Synders Bryst!

Endelig saa veed vi alle at selve Ordet "Evangelium" betyder et glædeligt Budskab, og at Julenats-Engelen bad Hyrderne ved Bethlehem være ved et frit Mod, da han kom for at forkynde dem en stor Glæde, og troer vi dette Evangelium, da veed vi ogsaa at Herrens Aar virkelig bringer en stor, en mageløs Glæde med sig, thi hvormeget end vore mange verdslige og fremmede Sorger hidtil kan have forhindret os fra ret at glæde os i Herren og glæde os altid, saa er Juleglæden over, at os er en Frelser født en guddommelig Frelser fra alt ondt, dog intet troende Hjerte fremmed og overgaaer selv i sit mindste Maal saavidt al Verdens Glæde, som Himlen er over Jorden!

See m. V. derfor sige vi med Sandhed, at jo fastere vi kan troe paa Guds Naade i Jesus Christus Vorherre, jo ivrigere vi søge Freden og Sjælens Hvile alene hos ham, i hans Frelsernavn, som kan rumme os alle, og jo inderligere vi længes efter at indgaae til vor Herres Glæde, des rigere Velsignelse vil Herrens Aar bringe os som Naadens, Fredens og Glædens Aar, der komme til os i hans Navn og med hans GuddomsKraft, fordi hans Ord til os er Aand og Liv!

Byder vi derfor kun af Hjertens Grund idag Herrens Aar velkommen til Jorden med ham selv, da han lod sig føde til Verdens Frelser i Davids Stad og velkommen herhid med hans Evangelium og Naademidler, da skal dette Kirkeaar visselig blive et christeligt Nytaar for os med en rig Velsignelse og gylden Høst, ja blive for vort Hjerte hvad Herrens Aar altid er for Guds Fader-Hjerte, et velbehageligt Aar, et Jubelaar og Gyldenaar! Det give Gud i Vorherres Jesu Christi Navn Amen! 


\title{
[Grundtvig-prædiken i Vartov, Fasc. 41]
}

\section{Nytaars-Dag 1850.}

\author{
Søde Jesus! Davids Rod! \\ Kæmpestærk og Barnegod \\ Kongesøn fra Englehjem, \\ Barnefødt i Bethlehem, \\ $\mathrm{Du}$, som giver Nytaar bedst! \\ Kom herind og vær vor Giæst! \\ Giør en liflig Jubelfest!
}

Ja, guddommelige Frelser og Gienløser! selv var Du Julegaven og din Aand er Nytaarsgaven, som din himmelske Fader af sin vidunderlige Naade har skiænket Adams faldne Kiøn! Rør Du os med din Aand til at modtage de himmelske Gaver med Taknemmelighed og lær os ved den samme Aand rettelig at bede Guds Børns Bøn: Fader vor! Du, som er i Himlene!

Vær velkommen, Herrens Aar og velkommen herhid!

Sandheds Gud! lad dit hellige Ord

Oplive, oplyse det høie Nord!

Velkommen Nytaar og velkommen her!

Naadens Gud! lad dit Soelskin i Vaar

Os skiænke paa Marken et gyldent Aar!

Fredens Gud! den livsalige Fred

Du skiænke vort Land til at blomstres ved!

Fader-Gud! os til Glæde og Gavn

Nytaaret henskride i Jesu Navn!

Velkommen Nytaar og velkommen her!

Saaledes synger og beder vi idag, og forsaavidt vi derved ene tænker paa Christen-Folket, for hvem Jesus Christus er baade Naaden og Sandheden og Lyset i guddommelig Forstand, Herrens Menighed, som søger Guds-Freden i Herrens Velsignelse, og søger Saligheden alene i Navnet, som af Engelen blev givet Bethlehems-Barnet, før han undfangedes i Moders Liv, Jesus-Navnet, hvori Frelseren lever og Frelsen lykkes til Dagenes Ende, forsaavidt istemmer alle Guds Engle vor Nytaars-Sang og forsaavidt opfylder den Himmelske Fader vort Nytaars-Ønske, saa vist, som Jesus er Hans elskelige Søn, i hvem Han finder Velbehag! Men naar vi idag, paa den borgerlige Nytaars-Dag, som oplyste Christne høitidelig bede Sandhedens, Naadens og Fredens Gud om et lyksaligt Nytaar, med Liv og Lys, med Fred og Glæde, da maae vore Tanker jo være henvendte til de verdslige Riger og borgerlige Selskaber og nærmest til det Rige og borgerlige Selskab, det Folk og Fæderneland, som vi 
efter Kiødet maa kalde vort eget og er med Blodets Baand inderlig knyttede til, hvorom Apostelen skriver, at dersom nogen af os ikke engang har Omsorg for sine egne, han er værre end en Vantro, værre end en Hedning, og naar det saaledes er paa det verdslige Riges og borgerlige Selskabs og nærmest paa det Danske Folks og Riges Vegne vi bede Sandhedens, Naadens og Fredens Gud om Liv og Frugtbarhed, om Lys og Lykke, Fred og Glæde, da maa det være i den Forstand, som Gud er ikke blot Christnes, men alle Menneskers Gud og Fader, og maa være hans gode Gaver i den Grad, som Han ogsaa hos Hedninger kan og vil give sin Naade og Godhed Vidnesbyrd, ved Regn og frugtbare Tider, ved at mætte dem ved Føde og deres Hjerter med Glæde.

Vi maae nemlig vide, at naar der tales om hele Folk, Riger og borgerlige Selskaber af denne Verden, som christelige, da er det kun løselig talt paa Verdens Sprog, saaledes som man kalder alle de Døbte Christne, skiøndt de ikke troe, og kalder alt christeligt hvad der blot minder om Christus og Christendommen, som den christelige Tidsregning og den udvortes christelige Gudsdyrkelse med Ordet og Sacramenterne, med Søndagen som Herrens Dag, med Jul og Paaske og Pindse som de christelige Høitider, uden at den Gud, som seer paa Hjertet kan lade sig blænde af det som kun er tilsyneladende, eller for det christelige Skins Skyld skiænke noget Verdens-Folk eller Rige den evige Velsignelse, der kun hører hans Hellige, hans Tilbedere i Aand og Sandhed, hans eget Folk og Rige til, med et Ord: Retfærdighed, Fred og Glæde i den Helligaand!

Men $\mathrm{m}$. V. det er dog ingenlunde blot i den synlige Verden, at Gud lader sin Soel opgaae over Onde og Gode og lader regne over Retfærdige og Uretfærdige, Han giør det ogsaa i den usynlige, i Ordets og Aandens Verden, saa vore lutherske Fædre havde fuldkommen Ret i, at de Folk og Lande var kiendelig og rigelig velsignede af Himlens Gud, i hvis Midte Han lod sin Naades Ord og Evangelium forkynde reent og purt med Aand og Salvelse og lod sine Naademidler virke med Kraft efter Herrens Indstiftelse, og at denne Guds Velsignelse blev kiendeligere og rigere i samme Grad, som baade Folket og Regieringen tillod Christi Ord at forkyndes frit og boe fredelig i Landet, saa Herrens Dag og hans Høitider blev holdt i Ære og bødes velkomne at være!

Og see m. V. kan vi nu sige med Sandhed, at der er intet Sted i Verden, hvor Gud i de senere Tider [har] ladet sin Søns Evangelium mere klart og kiærlig forkynde og hans Indstiftelser mere levende og frugtbar virke end i Danmark og hele vort Norden; og var der heller intet Sted, hvor Folket heller flokkedes for at høre Guds Ord varmt og levende forkyndt, intet Sted, hvor de bød Herrens Høitider og især Julen inderligere velkommen, da slutter vi deraf med Rette at Gud ogsaa fremdeles vil velsigne disse Folk, Riger og Lande med al den Fred og Frugtbarhed, Oplysning og Glæde, som de kan modtage og gierne annamme af Hans milde Haand, som er udrakt til at mætte alt Levende med Velbehagelighed. 
Vi tør derfor i Jesu Navn spaae ethvert Folk og Rige i denne Verden saa lyksaligt et Nytaar, som Julen for dem er en glædelig Fest, og var der end nærmest omkring os for nylig en Tid, da det syndes, som alle Herrens Høitider, selv Julen var blevet Folket modbydelige eller dog ligegyldige, og det glædelige Budskab om Frelserens Fødsel var blevet snarere til Spot end til Glæde, saa er den Tid dog Gud skee Lov! i det hele forbi hos os, saa det store Evangelium høres atter Aar for Aar med mere Lyst og Begiærlighed, Lovsangene paa Herrens Høitider istemmes atter Aar for Aar af talrige Skarer med mere inderlig Deltagelse og især bliver Julen atter Aar for Aar en glædeligere Fest baade i og udenfor Herrens Huus, saa vi tør sige at i Aandens og Hjertets Verden er Vinter-Soelhverven lagt tilbage, er Vaar og Sommer og Høst ivente, fordi Herren er god og Hans Miskundhed varer evindelig.

Saa vist som der da er en menneskelig Sandhed, Naade og Fredelighed, som i al deres jordiske Svaghed og Fattigdom dog er Himlens Gud behagelige og visse paa hans Velsignelse, saa vist tør vi ogsaa love ethvert Folk og Rige saa lyksaligt et Nytaar, som menneskelig Sandhed, det er Ærlighed og Sanddruhed, menneskelig Naade, som er Mildhed og Godgiørenhed, og menneskelig Fred, det er Livets rolige, uforstyrrede Virksomhed og Nydelse findes og skattes, og denne menneskelige Sandhed, Naade og Fred, som fra Arildstid har havt et kiendeligt Hjem i disse Nordens Egne, de findes og skattes Gud skee Lov! dog her endnu, om end langt mindre end vi maatte ønske, dog langt meer end andensteds, saa naar Himlens Gud klarlig viser, at ogsaa de er Ham behagelige, at Han er en Fiende ad al Løgn og Falskhed, en almægtig Beskytter af al Oprigtighed og Sanddruhed, en Fiende ad det Hjerteløse; en barmhjertig og naadig Gud for alt det Naadige og Hjertelige, en Hader af al Trættekiærhed, Kiv og Splid, som kalder alle de i Sandhed Fredsommelige sine Børn, da er der intet Land paa Jorden, som vil blomstre saa yndig, intet Folk under Solen, som da i saa høi en Grad vil fryde sig ved Livet som det Danske. - Om nu denne Guds Time vil slaae $\mathrm{i}$ det borgerlige Aar, vi idag begynde, det veed vi vel ikke, men vi bede trøstig i Jesu Navn, er det mueligt, da lad det skee, vi sige trøstig, er det virkelig godt i alle Maader, da skeer det visselig, og Herren vil ikke tøve et Øieblik længer end det behøves med at betale den Trængsel, som trængde og stræbde at fortrænge det lille, menneskelig talt uskyldige, oprigtige, miskundelige og fredelige Folk i vore Landemærker og at give dem som trængdes Hvile med os, saavidt som de kan modtage og vil søge den i den Almægtiges Skygge, og i Frelser-Navnet, som er det eneste under Solen, hvori Folk og Riger saavelsom hver enkelt især, kan finde hjertelig Fred, aandelig Opreisning og Helbredelse. Derfor vil vi ogsaa paa Danmarks Vegne sige og synge: velkommen Nytaar og velkommen her, sige og synge saa, til det kiendelig kommer fra Gud og da inderlig takke ham, som aldrig lader sig selv uden Vidnesbyrd, inderlig i Vorherres Jesu Navn Amen! 


\section{Forkortelser}

BG I-II: Georg Christensen og Stener Grundtvig (udg.) (1924-26), Breve fra og til N. F. S. Grundtvig, I (1807-20), II (1821-72), København.

Fasc.: Fascikel, dvs. håndskriftskapsel i Grundtvig-arkivet på Det Kongelige Bibliotek.

GP I-XII: Chr. Thodberg (udg.) (1983-86), N. F. S. Grundtvigs Prcedikener 1822-26 og 1832-39, I-XII, København.

GPV I-IV: Jette Holm m.fl. i samarbejde med Chr. Thodberg (udg.) (2003), Grundtvig Prcedikener $i$ Vartov, 1839-42, I-IV, inkl. kommentarbind (IV), København.

GSV I-VI: Th. Balslev m.fl. (udg.) (1944-64), Grundtvigs Sang-Vark. Samlet Udgave, I-VI, København.

US I-X: Holger Begtrup (udg.) (1904-09), Nik. Fred. Sev. Grundtvigs Udvalgte Skrifter, I-X, København.

\section{Litteraturliste}

\section{Voerker af Grundtvig}

Begtrup, Holger (1924), N. F. S. Grundtvigs Vartovs-Prcedikener 1839-1860. I Udvalg ved Holger Begtrup, København.

Grundtvig, N. F. S. (1839), "Frisprog mod H. H. Hr. Biskop Mynsters Forslag til en ny Forordnet Alterbog." i US VIII, 208-298.

— (1843), "Til Vilhelm Birkedal” og "Til P. Fenger" i BG II, 373-376.

- (1849-1850), "Vær velkommen Herrens Aar" og "Nytaars-Ønske” i GSV IV, 247 og 250.

— (1849), Prædiken i Vartov, 25de Treenigheds-Søndag 1849, www. grundtvigbyen.dk.

- (1849). Fascikel 40 i Grundtvig-arkivet på Det Kongelige Bibliotek. Nyt Kirke-Aar 1848-1849. 25de Treenigheds-Søndag 1849.

- (1849 og 1850). Fascikel 41 i Grundtvig-arkivet på Det Kongelige Bibliotek. Nyt Kirke-Aar 1849-50. 1ste Advents-Søndag 1849 og Nytaarsdag 1850.

Holm, Jette m.fl. i samarbejde med Chr. Thodberg (udg.) (2003), Grundtvig Prcedikener $i$ Vartov 1839-42, II med kommentarbind IV, København.

Thodberg, Christian (udg.) (1985), N. F. S. Grundtvigs Prcedikener 1822-26 og 1832-39, X, København.

\section{Voerker af andre forfattere}

Birchedahl, Vilhelm (1843), Kirkeaaret, et Billede paa den christelige Livsudvikling, København.

Brandt, C. J. (1874), "Et Udkast af Grundtvig til en ny Tekst-Række af SøndagsEvangelier", Dansk Kirketidende 1874 (6), 81-86.

Malling, Anders (1962-1978), Dansk Salmehistorie, I-VIII, København. 